\title{
PENGARUH LIKUIDITAS, LEVERAGE, INTENSITAS MODAL, DAN UKURAN PERUSAHAAN TERHADAP AGRESIVITAS PAJAK
}

\author{
Hadi Cahyadi ${ }^{1}$, Catherine Surya ${ }^{2}$, Henryanto Wijaya ${ }^{3}$, dan Susanto Salim ${ }^{4}$ \\ Universitas Tarumanagara ${ }^{1,2,3,4}$ \\ E-mail: henryanto.wijaya@gmail.com
}

\begin{abstract}
In this study aims to examine the impact of liquidity, leverage, capital intensity, and firm size as moderation variable to tax aggressiveness in listed manufacturing entities in IDX (Indonesian Stock Exchange) period 2015-2018. This study use 65 manufacturing companies as sample in this study and also use multiple regression analysis. Results of this study indicate that liquidity were'nt significant negative to tax aggressiveness, and leverage were significant positive to tax aggressiveness, capital intensity not significant positive to tax aggressiveness, firm size not significant negative to tax aggressiveness, firm size is able to moderate liquidity, leverage, and capital intensity to tax aggressiveness.
\end{abstract}

Keywords : liquidity, leverage, capital intensity, firm size, tax aggressiveness.

\section{Pendahuluan}

Indonesia ialah salah satu dari negara berkembang dengan jumlah penduduk yang besar, memiliki SDA (Sumber Daya Alam) yang melimpah dan terletak pada kondisi geografis yang strategis. Kondisi ini tercermin melalui banyaknya perusahaan di Indonesia, sehingga kontribusi penerimaan pajak dalam APBN (Anggaran Pendapatan dan Belanja Negara) semakin meningkat. Realisasi dari penerimaan pajak negara periode 2015 hingga 2018 mengalami peningkatan yang berkesinambungan. Penerimaan pajak tahun 2015 sebesar $67 \%$ dari keseluruhan penerimaan negara atau setara dengan Rp. 1.201,7 triliun. Tahun 2016 total penerimaan negara adalah sebesar Rp. 1.822,5 triliun, Rp. 1.546,7 triliun diantaranya adalah berasal dari penerimaan pajak. Peningkatan pada tahun 2017 dimana 85,6\% atas penerimaan negara berasal dari penerimaan pajak atau setara dengan Rp. 1.498,9 triliun. Demikian pula tahun 2018 dengan penerimaan pajak sebesar $85,40 \%$ dari penerimaan negara dimana total penerimaan negara sebesar Rp. 1.894,7 triliun. Perusahaan merupakan Wajib Pajak dan berkontribusi besar terhadap penerimaan negara. Hal ini tercermin dari jumlah pajak yang dibayarkan perusahaan setiap periodenya. Sementara itu, perusahaan selalu menganggap pajak merupakan beban yang mengurangi laba perusahaan, sehingga perusahaan berusaha melakukan upaya untuk mengurangi beban pajaknya. Disisi lain, pemerintah menginginkan pajak yang optimal untuk membiayai rencana pembangunan negara. Perbedaan kepentingan antara Wajib Pajak dengan pemerintah menyebabkan adanya upaya mengurangi pembayaran pajak oleh Wajib Pajak yang disebut tindakan agresif dalam perpajakan atau agresivitas pajak (Suyanto \& Supramono, 2012). Menurut Frank, Lynch dan Rego (2009), agresivitas pajak entitas merupakan suatu tindakan untuk merekayasa Penghasilan Kena Pajak oleh entitas melalui cara yang legal atau dikenal sebagai tax avoidance, ataupun cara yang ilegal (tax evasion).

Berdasarkan penelitian yang dilakukan oleh Zulaikha dan Ardyansah (2014) menguraikan bahwa leverage tidak memiliki pengaruh yang signifikan terhadap effective tax rate. Sementara itu, penelitian yang dilakukan oleh Ariani dan Hasymi (2018) menyatakan leverage memiliki hubungan positif signifikan terhadap effective tax rate. Penelitian yang dilakukan Juliani dan Nugroho (2018) menguraikan bahwa intensitas modal tidak memiliki 
pengaruh signifikan terhadap effective tax rate. Sedangkan penelitian yang dilakukan Andreas dan Savitri (2017) menunjukkan bahwa intensitas modal memiliki pengaruh negatif signifikan terhadap effective tax rate. Disisi lain, Darsono dan Muzakki (2015) menunjukkan hasil penelitian bahwa intensitas modal berpengaruh signifikan positif terhadap effective tax rate. Penelitian yang dilakukan oleh Zulaikha dan Ardyansah (2014) menunjukkan bahwa ukuran perusahaan berpengaruh negatif signifikan terhadap agresivitas pajak. Sedangkan penelitian yang dilakukan oleh Prameswari (2017) menguraikan bahwa ukuran perusahaan tidak mempengaruhi agresivitas pajak. Penelitian ini dimaksudkan agar sistem perpajakan di Indonesia dapat terlaksana lebih efisien serta efektif seiring dengan pertumbuhan dari dunia bisnis. Maka dari itu, penelitian ini berupaya mengintegrasikan penelitian-penelitian sebelumnya dengan menganalisis kembali pengaruh dari likuiditas, leverage, dan intensitas modal terhadap agresivitas pajak dengan ukuran perusahaan sebagai variabel moderasi. Subjek dari penelitian ini berbeda dengan penelitian terdahulu karena menggunakan perusahaan manufaktur yang terdaftar dalam BEI (Bursa Efek Indonesia) periode 2015 hingga 2018 dan menggunakan variabel moderasi berupa ukuran perusahaan.

\section{Tinjauan Literatur dan Pengembangan Hipotesis}

Agency Theory. Berdasarkan penelitian Jensen dan Meckling (1976) menjelaskan masalah keagenan (agency problem) timbul karena adanya ketidak samaan kepentingan antara dua pihak, yaitu stockholders (principle) dan pihak manajemen (agent). Perbedaan kepentingan antara Wajib Pajak dengan pemerintah menyebabkan adanya upaya mengurangi pembayaran pajak oleh Wajib Pajak yang disebut tindakan agresif dalam perpajakan atau agresivitas pajak (Suyatno \& Supramono, 2012).

Likuiditas. Menurut Kieso, Weygandt, dan Warfield (2018), likuiditas dapat menunjukkan kemampuan suatu entitas bisnis dalam menyelesaikan liabilitas jangka pendek yang jatuh tempo dalam waktu dekat dan kemampuan perusahaan untuk menghadapi kondisi mendesak yang membutuhkan dana.

Leverage. Brooks (2013, h. 459) menjelaskan definisi leverage sebagai berikut: " $a$ company's ability to meet its long term debt obligation", yang artinya leverage menunjukkan kemampuan suatu perusahaan dalam melakukan pendanaan.

Intensitas Modal. Menurut Nugraha dan Meiranto (2015), intensitas modal didefinisikan bagaimana suatu perusahaan akan melakukan pengorbanan dalam mengeluarkan fund untuk kegiatan operasional dan mendanai aset demi memperoleh laba.

Ukuran perusahaan. Definisi dari ukuran perusahaan ialah sebuah pengukuran dengan mengelompokkan besar dan kecilnya suatu entitas dan menggambarkan berbagai aktivitas serta laba entitas tersebut. Ukuran perusahaan mencerminkan kemampuan dan kestabilan perusahaan dalam menghasilkan laba, artinya semakin besar penghasilan bersih suatu entitas maka semakin berukuran besar pula perusahaan tersebut (Suyanto \& Supramono, 2012).

Hipotesis Penelitian:

$\mathrm{Ha}_{1}$ : Likuiditas berpengaruh negatif dan signifikan terhadap agresivitas pajak entitas.

$\mathrm{Ha}_{2}$ : Leverage berpengaruh positif dan signifikan terhadap agresivitas pajak entitas.

$\mathrm{Ha}_{3}$ : Intensitas modal berpengaruh positif dan signifikan terhadap agresivitas pajak entitas.

$\mathrm{Ha}_{4}$ : Ukuran perusahaan berpengaruh negatif dan signifikan terhadap agresivitas pajak entitas.

Ha5: Ukuran perusahaan memperkuat pengaruh likuiditas terhadap agresivitas pajak entitas.

$\mathrm{Ha}_{6}$ : Ukuran perusahaan memperlemah pengaruh leverage terhadap agresivitas pajak entitas.

Ha7: Ukuran perusahaan memperlemah pengaruh intensitas modal terhadap agresivitas pajak entitas. 
Berikut kerangka pemikiran yang digunakan dalam penelitian ini:

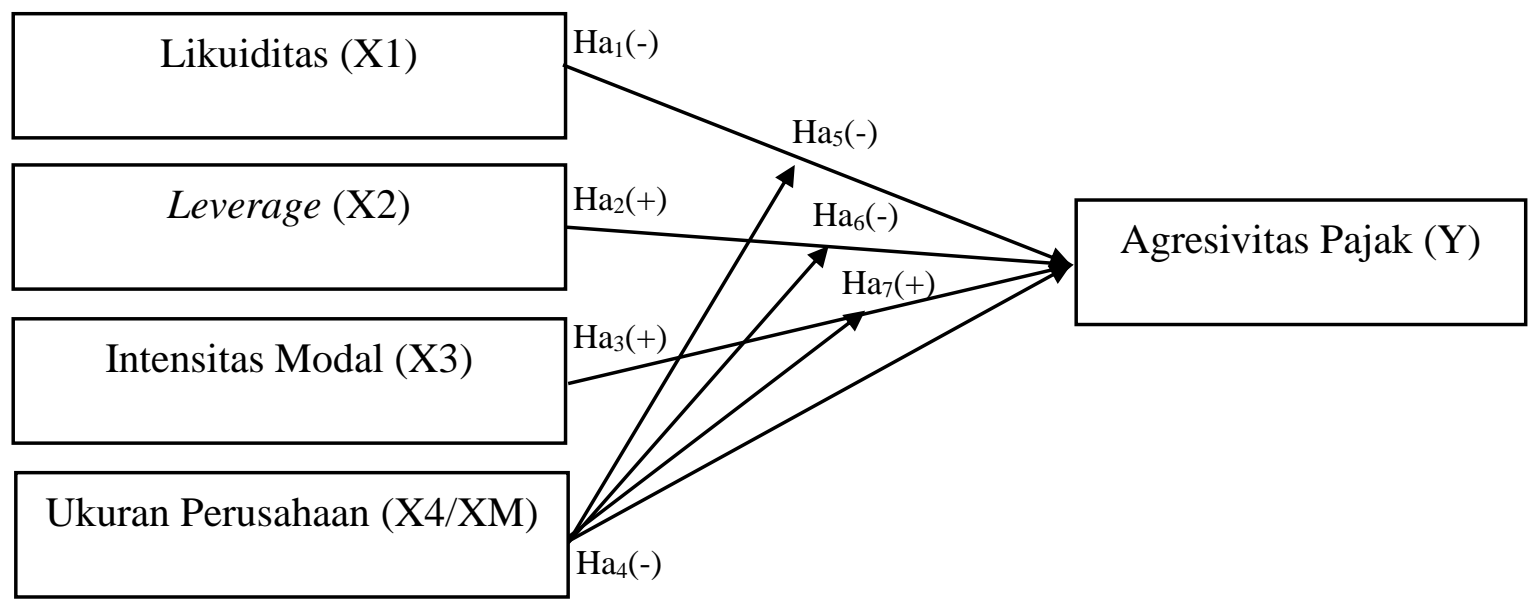

Gambar 1. Kerangka Pemikiran dan Hipotesis

Sumber: Pengolahan data oleh Penulis, 2019

\section{Metode Penelitian}

Penelitian ini menerapkan data sekunder yang diperoleh berasal dari laporan keuangan entitas manufaktur yang terdaftar dalam BEI (Bursa Efek Indonesia) tahun 2015 hingga 2018. Metode pengambilan sampel yang diterapkan dalam penelitian ini ialah purposive sampling. Purposive sampling didefinisikan "a non-probability sample that conforms to certain criteria" (Cooper dan Schindler, 2011, h. 385).

Penentuan sampel menggunakan kriteria sebagai berikut: (1) Entitas manufaktur yang secara konsisten terdaftar di BEI (Bursa Efek Indonesia) periode 2015-2018; (2) Perusahaan memiliki laporan keuangan lengkap dan telah diaudit; (3) Perusahaan menggunakan mata uang Rupiah; (4) Perusahaan bertahun buku laporan keuangan 1 Januari sampai 31 Desember; (5) Perusahaan tidak mengalami kerugian sebelum pajak selama periode 20152018; (6) Perusahaan tidak mengalami kerugian setelah pajak selama periode 2015-2018; (7) Perusahaan tidak memperoleh income tax benefits selama periode 2015-2018.

Penelitian ini secara keseluruhan menggunakan lima variabel, yaitu agresivitas pajak, likuiditas, leverage, intensitas modal dan ukuran perusahaan. Adapun perhitungan masingmasing variabel dijelaskan sebagai berikut:

a. Agresivitas Pajak

$$
\text { Effective Tax Rate }=\frac{\text { Income Tax Expense }}{\text { Pre Tax Income }}
$$

b. Likuiditas

$$
\text { Current Ratio }=\frac{\text { Current Asset }}{\text { Current Liabilities }}
$$

c. Leverage

$$
\text { Debt to Equity Ratio }=\frac{\text { Total Liabilities }}{\text { Total Equity }}
$$

d. Intensitas Modal

$$
\text { Capital Intensity Ratio }=\frac{\text { Fixed Asset }}{\text { Total Assets }}
$$

e. Ukuran Perusahaan

Size $=\operatorname{Ln}$ (Sales) 
Selanjutnya, data yang telah diperoleh diolah dengan menggunakan software Econometric Views (EViews) versi 10. Dilakukan berbagai uji pada penelitian ini yang terdiri atas uji statistik deskriptif dan estimasi model data panel yang meliputi uji Chow dan uji Hausman sedangkan dalam pengujian hipotesis dilakukan uji simultan (uji F), uji koefisien determinasi berganda $\left(\mathrm{R}^{2}\right)$, dan uji parsial (uji t).

\section{Hasil Penelitian dan Pembahasan}

Statistik Deskriptif. Fungsi dari statistik deskriptif ialah untuk menganalisa data dengan cara mendeskripsikan informasi terkait nilai dari mean, nilai minimum, nilai maksimum, nilai deviasi standar, dan jumlah observasi dari kelompok data dalam suatu penelitian. Variabel agresivitas pajak mempunyai nilai dari minimum senilai 0.012421 , nilai dari maximum senilai 0.971211 , nilai dari mean senilai 0.274170 , dan nilai standar deviasi sebesar 0.129948 . Variabel likuiditas mempunyai nilai dari minimum senilai 0.584216 , nilai dari maximum senilai 15.164600, nilai dari mean senilai 2.756613, dan nilai dari standar deviasi senilai 2.087818. Variabel leverage memiliki nilai dari minimum senilai 0.076125 , nilai dari maximum senilai 4.546886 , nilai dari mean senilai 0.811784 , dan nilai dari standar deviasi senilai 0.704645 . Variabel intensitas modal mempunyai nilai dari minimum senilai 0.033865 , nilai dari maximum senilai 0.796561 , nilai dari mean senilai 0.361226 , dan nilai dari standar deviasi senilai 0.159119. Variabel ukuran perusahaan mempunyai nilai dari minimum senilai 25.360370, nilai dari maximum senilai 33.108340, nilai dari mean senilai 28.573210, dan nilai dari standar deviasi senilai 1.677410 .

Estimasi Model Data Panel. Uji Likehood (Chow test) didapatkan hasil bahwa dari nilai probabilitas cross-section chi-square memiliki nilai 0,0000 yang mengartikan nilai itu lebih kecil dari a (5\%) maka $\mathrm{H}_{0}$ akan ditolak, Jadi dapat ditarik kesimpulan bahwa model yang tepat untuk dipilih berdasarkan hasil uji Likehood (Chow test)yang telah dilakukan adalah fixed effect model. Berdasarkan hasil kesimpulan tersebut maka uji penelitian yang akan dilakukan selanjutnya adalah uji hausman. Berdasarkan uji Hausman, didapatkan hasil bahwa dari nilai probabilitas cross-section random memiliki nilai 0,0350 yang mengartikan nilai itu lebih kecil dari $\alpha(5 \%)$ maka $\mathrm{H}_{0}$ akan ditolak, Jadi dapat ditarik kesimpulan bahwa model yang tepat untuk dipilih berdasarkan hasil uji Hausman yang telah dilakukan adalah fixed effect model.

Hipotesis yang digunakan di penelitian ini akan diterapkan pengujian dengan menggunakan sebuah model regresi linear berganda. Model regresi linear berganda yang terdapat dalam penelitian ini sebagai berikut:

ETR $=0.206309_{\mathrm{i}, \mathrm{t}}-0.057130 \mathrm{LIK}_{\mathrm{i}, \mathrm{t}}+0.002186 \mathrm{LIK}_{\mathrm{i}, \mathrm{t}} \mathrm{x} \mathrm{SIZE}_{\mathrm{i}, \mathrm{t}}+1.620460 \mathrm{LEV}_{\mathrm{i}, \mathrm{t}}-0.053048$ $\mathrm{LEV}_{\mathrm{i}, \mathrm{t}} \times \mathrm{SIZE}_{\mathrm{i}, \mathrm{t}}+0.486863$ CAPIN $_{\mathrm{i}, \mathrm{t}}-0.015023$ CAPIN $_{\mathrm{i}, \mathrm{t}} \times \mathrm{SIZE}_{\mathrm{i}, \mathrm{t}}-0.001583 \mathrm{SIZE}_{\mathrm{i}, \mathrm{t}}+\varepsilon_{\mathrm{i}, \mathrm{t}}$

Persamaan regresi diatas menginterpretasikan bahwa konstanta mempunyai nilai koefisien regresi sebesar 0,206309 yang menjelaskan bahwa effective tax rate akan bernilai 0,206309 jika nilai likuiditas, leverage, intensitas modal, ukuran perusahaan, likuiditas dengan moderasi ukuran perusahaan, leverage dengan moderasi ukuran perusahaan, dan intensitas modal dengan moderasi ukuran perusahaan sama dengan nol. Likuiditas perusahaan mempunyai nilai koefisien regresi sebesar negatif 0,057130 . Koefisien regresi tersebut bernilai negatif menunjukkan likuiditas entitas memiliki pengaruh negatif terhadap effective tax rate. Likuiditas dengan moderasi ukuran entitas mempunyai nilai koefisien regresi senilai 0,002186 .

Koefisien regresi tersebut menunjukan nilai positif bahwa likuiditas dengan moderasi ukuran entitas memiliki pengaruh positif terhadap effective tax rate. Leverage perusahaan 
mempunyai nilai koefisien regresi sebesar 1,620460 dan memiliki nilai positif menunjukkan leverage entitas memiliki pengaruh positif terhadap effective tax rate. Leverage dengan moderasi ukuran entitas mempunyai nilai koefisien regresi sebesar negatif 0,053048 dan memiliki nilai negatif yang menunjukkan bahwa leverage dengan moderasi ukuran entitas memiliki pengaruh negatif terhadap effective tax rate. Intensitas modal entitas mempunyai nilai koefisien regresi sebesar 0,486863 dan memiliki nilai positif menunjukkan intensitas modal perusahaan memiliki pengaruh positif terhadap effective tax rate. Intensitas modal dengan moderasi ukuran perusahaan mempunyai nilai koefisien regresi sebesar negatif 0,015023 dan memiliki nilai negatif yang menunjukkan bahwa intensitas modal dengan moderasi ukuran perusahaan memiliki pengaruh negatif terhadap effective tax rate. Ukuran entitas mempunyai nilai koefisien regresi sebesar negatif 0,001583 dan memiliki nilai negatif yang menunjukkan bahwa ukuran perusahaan memiliki pengaruh negatif terhadap effective tax rate.

Uji Simultan (Uji F). Agar dapat mengetahui apakah seluruh variabel independen secara simultan mempengaruhi variabel dependen. Hasil uji $\mathrm{F}$ menginterpretasian nilai probability (F-statistic) adalah sebesar 0,000000 , dimana nilai probability ( $F$-statistic) $<0,05$ membuktikan bahwa $\mathrm{H}_{0}$ ditolak, artinya likuiditas, leverage, dan intensitas modal dengan pemoderasi ukuran entitas secara simultan memiliki pengaruh signifikan terhadap agresivitas pajak.

Uji Koefisien Determinasi Berganda $\left(\mathbf{R}^{2}\right)$. Agar dapat mengetahui apakah variabel independen dapat menjelaskan variasi dari variabel dependen dalam sebuah penelitian. Hasil uji koefisien determinasi berganda menginterpretasikan nilai dari Adjusted $R$-squared adalah senilai 0,563235 yang menginterpretasikan bahwa variabel bebas yaitu likuiditas, leverage, dan intensitas modal dengan pemoderasi ukuran perusahaan mampu menjelaskan variabel terikat pada penelitian ini berupa agresivitas pajak senilai 0,563235 atau setara dengan $56,32 \%$. Sisanya senilai 0,436765 atau setara dengan 43,68\% menjelaskan bahwa agresivitas pajak juga dipengaruhi faktor lain selain likuiditas, leverage, dan intensitas modal dengan pemoderasi ukuran perusahaan.

Uji Parsial (Uji t). Uji parsial diterapkan guna mengetahui apakah variabel independen secara individual mempengaruhi variabel dependen.

Tabel 1. Hasil Uji Parsial (Uji t)

Dependent Variable: Y_ETR

Method: Panel Least Squares

Date: 12/06/19 Time: 02:04

Sample: 20152018

Periods included: 4

Cross-sections included: 65

Total panel (balanced) observations: 260

\begin{tabular}{lllll}
\hline \hline Variable & Coefficient & Std. Error & t-Statistic & Prob. \\
\hline \hline C & 0.206309 & 1.630420 & 0.126538 & 0.8994 \\
X1_LIK & -0.057130 & 0.123568 & -0.462334 & 0.6444 \\
X1M & 0.002186 & 0.004548 & 0.480671 & 0.6313 \\
X2_LEV & 1.620460 & 0.641667 & 2.525393 & 0.0124 \\
X2M & -0.053048 & 0.022222 & -2.387158 & 0.0180 \\
X3_CAPIN & 0.486863 & 2.529278 & 0.192491 & 0.8476
\end{tabular}




$\begin{array}{lllll}\text { X3M } & -0.015023 & 0.089747 & -0.167398 & 0.8672 \\ \text { M_SIZE } & -0.001583 & 0.057358 & -0.027597 & 0.9780\end{array}$

Dependent Variable: Agresivitas Pajak

Sumber: Pengolahan data dengan software EViews Versi 10.

Hasil uji parsial (uji t) menunjukkan bahwa variabel likuiditas, variabel intensitas modal, variabel ukuran perusahaan, variabel likuiditas dengan pemoderasi ukuran perusahaan, serta variabel intensitas modal dengan pemoderasi ukuran entitas tidak memiliki pengaruh signifikan terhadap variabel agresivitas pajak. Hal ini dikarenakan nilai signifikansi dari variabel-variabel tersebut lebih besar dari nilai 0,05. Sedangkan untuk variabel leverage dan variabel leverage dengan pemoderasi ukuran entitas memiliki pengaruh yang signifikan terhadap agresivitas pajak. Hal ini dikarenakan nilai signifikansi dari variabel-variabel tersebut lebih kecil dari nilai 0,05 .

Berdasarkan dari hasil pengujian hipotesis yang sudah dilakukan, diperoleh hasil likuiditas entitas tidak memiliki pengaruh yang signifikan terhadap agresivitas pajak. Adapun hasil penelitian ini sejalan dengan penelitian yang diterapkan oleh Tiaras dan Wijaya (2015), Nurjanah et al. (2018), Ariani dan Hasymi (2018) yang menunjukkan bahwa likuiditas perusahaan tidak berpengaruh signifikan terhadap agresivitas pajak. Insignifikannya hubungan antara likuiditas entitas dengan tingkat agresivitas pajak dapat disebabkan oleh tingkat likuiditas pada entitas manufaktur yang relatif sama. Leverage berpengaruh positif serta signifikan terhadap agresivitas pajak. Adapun hasil penelitian ini sejalan dengan penelitian yang diterapkan oleh Lestari et al. (2019), Ariani dan Hasymi (2018) yang menjelaskan leverage entitas memiliki pengaruh yang positif dan signifikan terhadap agresivitas pajak. Hal ini terjadi karena perusahaan dengan leverage yang tinggi menyebabkan beban bunga semakin besar dan Penghasilan Kena Pajak menjadi kecil, sehingga semakin tinggi tingkat agresivitas pajak. Agency Theory menjelaskan bahwa pemegang saham (principle) menggunakan rasio leverage untuk menilai kemampuan manajemen (agent) dalam mengelola utang perusahaan dalam memenuhi kebutuhan investasi dan operasional perusahaan, termasuk juga pembayaran utang yang segera jatuh tempo.

Intensitas modal tidak memiliki pengaruh signifikan terhadap agresivitas pajak. Adapun hasil penelitian ini searah dengan penelitian yang diterapkan oleh Zulaikha dan Ardyansah (2014), Nugraha dan Meiranto (2015), Indrajati et al. (2017), Juliani dan Nugroho (2018), serta Henny (2019) yang menunjukkan intensitas modal perusahaan tidak berpengaruh signifikan terhadap agresivitas pajak. Hal ini dikarenakan bebarapa perusahaan mempunyai aset tetap yang sudah habis manfaat ekonominya tetapi tidak dihentikan pengakuannya dan untuk aset bergerak seperti kendaraan jika dibawa pulang oleh penggunanya maka tidak semua biaya penyusutan atau pemeliharaan dapat dibebankan melainkan hanya sebesar 50\%. Adanya perlakuan terhadap biaya penyusutan terhadap aset tetap dapat mempengaruhi perhitungan jumlah pajak yang ditanggung perusahaan. Ukuran perusahaan tidak memiliki pengaruh yang signifikan terhadap agresivitas pajak. Adapun hasil penelitian memiliki pendapat yang sejalan dengan penelitian yang diterapkan oleh Prameswari (2017) bahwa ukuran entitas tidak memiliki pengaruh signifikan terhadap agresivitas pajak. Adapun hal ini diakibatkan besarnya ukuran suatu entitas maka entitas tersebut mempunyai lebih sedikit kemungkinan untuk melakukan upaya penghindaran pajak (aggressive tax planning). Ukuran suatu entitas dapat diukur melalui besarnya penjualan perusahaan. Jika entitas semakin besar, maka going concern atau kelangsungan usaha dari entitas tersebut semakin baik. Entitas yang besar ataupun telah lama beroperasi memiliki kecenderung mempunyai praktisi pajak yang sungguh-sungguh memahami peraturan perpajakan. 
Likuiditas dengan ukuran perusahaan sebagai variabel moderasi tidak memiliki pengaruh signifikan terhadap agresivitas pajak. Namun ukuran entitas memperkuat hubungan antara likuiditas dengan agresivitas pajak entitas, hal ini terjadi dikarenakan suatu entitas dikategorikan besar apabila tingkat penjualan perusahaan tersebut tinggi dan mempengaruhi besarnya laba perusahaan. Tingkat penjualan yang tinggi akan memperbesar kas serta piutang perusahaan sehingga tingkat likuiditas perusahaan juga tinggi. Semakin tinggi laba suatu entitas menyebabkan semakin tinggi juga pajak yang harus dibebankan perusahaan tersebut sehingga perusahaan cenderung berupaya untuk memperkecil beban pajak sehingga tingkat agresivitas pajak perusahaan tinggi. Leverage dengan ukuran perusahaan sebagai variabel moderasi memiliki pengaruh signifikan terhadap agresivitas pajak. Dimana ukuran entitas memperlemah hubungan leverage terhadap agresivitas pajak entitas, hal ini terjadi karena perusahaan dalam menjalankan operasionalnya memerlukan pembiayaan, salah satunya melalui utang. Tingkat utang yang tinggi akan memperbesar beban bunga yang harus dibayarkan perusahaan, dimana beban bunga akan memperkecil laba perusahaan. Disisi lain, suatu perusahaan dikategorikan besar apabila tingkat penjualannya tinggi. Tingkat penjualan yang tinggi akan memperbesar laba perusahaan, sehingga perusahaan dianggap mampu melunasi kewajibannya seperti beban bunga dan beban pajak. Dalam hal ini, tingkat beban bunga atas utang yang tinggi tidak mempengaruhi tingkat agresivitas pajak perusahaan karena dapat ditutupi oleh besarnya tingkat penjualan dan laba perusahaan.

Intensitas modal dengan ukuran entitas sebagai variabel moderasi tidak memiliki pengaruh signifikan terhadap agresivitas pajak. Namun ukuran entitas memperlemah hubungan antara intensitas modal dengan agresivitas pajak perusahaan, hal ini terjadi karena Suatu perusahaan dikategorikan besar apabila tingkat penjualannya tinggi. Tingkat penjualan yang tinggi memerlukan jumlah aset tetap yang besar untuk mendukung operasional perusahaan. Semakin banyak aset tetap yang perusahaan miliki maka semakin tinggi beban depresiasi yang mengakibatkan laba perusahaan menjadi kecil. Disisi lain, tingginya tingkat penjualan akan menyebabkan laba perusahaan. Beban depresiasi tersebut dapat ditutupi dan sejalan dengan laba atas penjualan perusahaan, sehingga jumlah aset tetap yang besar tidak berpengaruh signifikan terhadap beban pajak maupun tingkat agresivitas pajak.

\section{Simpulan dan Saran}

Simpulan. Berdasarkan dari hasil uji hipotesis yang telah diterapkan dalam penelitian ini, dapat ditarik sebuah kesimpulan bahwa variabel likuiditas, variabel intensitas modal, variabel ukuran entitas tidak memiliki pengaruh signifikan terhadap agresivitas pajak. Sedangkan variabel leverage berpengaruh positif dan signifikan terhadap agresivitas pajak. Ukuran perusahaan tidak memoderasi pengaruh likuiditas dan intensitas modal terhadap agresivitas pajak. Ukuran entitas memoderasi pengaruh dari leverage terhadap agresivitas pajak.

Saran. Penelitian yang akan dilakukan selanjutnya dapat memperluas ruang lingkup penelitian dengan menggunakan populasi berupa perusahaan sektor lain selain manufaktur, penelitian selanjutnya dapat memperpanjang periode penelitian, penelitian selanjutnya dapat menambah variabel-variabel selain likuiditas, leverage, intensitas modal, dan ukuran perusahaan yang mempengaruhi agresivitas pajak, serta dapat menggunakan variabel moderasi selain ukuran perusahaan.

\section{DAFTAR PUSTAKA}

Andreas \& Savitri, E. (2017). Determinants of Effective Tax Rate of the Top 45 Largest Listed Companies of Indonesia. International Journal of Management Excellence, 9(3), 1183-1188.

Ariani, M., \& Hasymi, M. (2018). Pengaruh Profitabilitas, Likuiditas, Leverage, Size, dan 
Capital Intensity Ratio Terhadap Effective Tax Rate (ETR). Komunikasi Ilmiah Akuntansi dan Perpajakan, 11(3), 452-463.

Brooks, R. (2009). Financial Management Core Concepts. United Kingdom: Pearson Education.

Cooper, D. R., \& Schindler, P. S. (2011). Business Research Methods. Newyork: McGrawHill Education.

Darsono \& Muzakki, M. R. (2015). Pengaruh Corporate Social Responsibility dan Capital Intensity Terhadap Penghindaran Pajak. Diponegoro Journal of Accounting, 4 (3), 1-8.

Frank, M. M., Lynch, L. J., \& Rego, S. O. (2009). Tax Reporting Aggressiveness and Its Relation to Aggressive Financial Reporting. The Accounting Review, 84(2), 467-496.

Henny. (2019). Pengaruh Manajemen Laba dan Karakteristik Perusahaan Terhadap Tax Avoidance. Jurnal Muara Ilmu Ekonomi dan Bisnis, 3(1), 36-46.

Indrajati, D., Djumena, S., \& Yuniarwati. (2017). Faktor-faktor yang Mempengaruhi Agresivitas Pajak pada Perusahaan Manufaktur yang Terdaftar di BEI 2013-2015. Jurnal Muara Ilmu Ekonomi dan Bisnis, 1(1), 125-134.

Jensen, M., \& Meckling, W. (1976). Theory of the firm: Managerial Behavior, Agency Cost and Ownership Structure. Journal of Financial Economic, 3(4), 305-360.

Juliani \& Nugroho, V. (2018). Faktor-faktor yang Mempengaruhi Tarif Pajak Efektif Perusahaan Manufaktur yang Terdaftar di BEI. Jurnal Multiparadigma Akuntansi Tarumanagara, 1(1).

Kieso, D. E., Weygandt, J. J., \& Warfield, T. D. (2018). Intermediate Accounting: IFRS Edition. Singapore: Markono Print Media.

Lestari, P. A. S., Pratomo, D., \& Asalam, A. G. (2019). Pengaruh Koneksi Politik dan Capital Intensity Terhadap Agresivitas Pajak. Jurnal ASET (Akuntansi Riset), 11(1), 40-52.

Nugraha, N. B., \& Meiranto, W. (2015). Pengaruh Corporate Social Responsibility, Ukuran Perusahaan, Profitabilitas, Leverage dan Capital Intensity terhadap Agresivitas Pajak. Diponegoro Journal of Accounting, 4(4), 1-14.

Nurjanah, I., Hanum, A. N., \& Alwiyah. (2018). Pengaruh Likuiditas, Leverage, Corporate Social Responsibility, Ukuran Perusahaan dan Komisaris Independen terhadap Agresivitas Pajak Badan. Prosiding Seminar Nasional Mahasiswa Unimus, 1, 432-438.

Prameswari, F. (2017). Pengaruh Ukuran Perusahaan terhadap Agresivitas Pajak dengan Corporate Social Responsibility sebagai Variabel Moderasi. Jurnal Ekonomi Akuntansi, 3(4), 74-90.

Suyanto, K. D., \& Supramono. (2012). Likuiditas, Leverage, Komisaris Independen, dan Manajemen Laba terhadap Agresivitas Pajak Perusahaan. Jurnal Keuangan dan Perbankan, 16(2), 167-177.

Tiaras, I., \& Wijaya, H. (2015). Pengaruh Likuiditas, Leverage, Manajemen Laba, Komisaris Independen dan Ukuran Perusahaan terhadap Agresivitas Pajak. Jurnal Akuntansi, 19(3), 380-397.

Zulaikha \& Ardyansah, D. (2014). Pengaruh Size, Leverage, Profitability, Capital Intensity Ratio dan Komisaris Independen terhadap Effective Tax Rate. Diponegoro Journal of Accounting, 3(2),1-9.

https://www.idx.co.id/

https://www.kemenkeu.go.id/dataapbn

http://www.sahamok.com 